\title{
CFC Legislation and EC Law
}

\author{
Otmar Thömmes, Deloitte Touche Thomatsu, München, Germany
}

To date, ECJ case law on direct taxation matters has tended to impose restrictions on anti-avoidance legislation in effect in EU Member States. ${ }^{1}$ The most recent and most noteworthy instance of this tendency is to be found in the decision in Lankhorst-Hohorst, ${ }^{2}$ where the ECJ held that the German thin capitalization rules in s. $8 \mathrm{a}$ of the CITA are incompatible with the freedom of establishment principle in Art. 43 of the EC Treaty.

Another type of anti-avoidance legislation applied by an increasing number of EU Member States takes the form of controlled foreign company (CFC) legislation, ${ }^{3}$ although the issue of whether CFC rules are compatible with the EC Treaty has not yet been raised at the ECJ. In its decision of 20 March 2002, the Finnish Supreme Administrative Court failed to take the opportunity to submit a case dealing with the Finnish CFC rules to the ECJ.

Anti-avoidance legislation in the EU has at least one common feature: all the rules make a fundamental distinction between domestic and foreign investments or between domestic and foreign corporations. This traditional approach of distinguishing between the domestic sphere and the foreign sphere does not take into consideration the existence of the new element represented by the European Internal Market. According to ECJ case law, it is necessary to take a critical look at any distinction between 'domestic' and 'foreign'.

All CFC rules operate in a similar fashion - in essence, income earned by a foreign subsidiary is deemed to be distributed to the domestic parent company if certain conditions are met. Usually, these conditions require the domestic parent to have a majority or at least a qualified ownership interest in the foreign subsidiary and the foreign subsidiary generally must be subject to low taxation. Some Member States have defined low-tax jurisdictions by reference to a 'black list' appended to their CFC law. ${ }^{4}$

Because foreign companies (i.e. companies incorporated under the laws of another Member State) are not subject to CFC rules, which apply exclusively to domestic parent companies, CFC laws are clearly not discriminatory. However, ECJ case law regarding the fundamental freedoms has developed over the years away from merely prohibiting discrimination to comprehensively prohibiting restrictions. The EC Treaty has been interpreted as prohibiting a Member State from imposing restrictions on its own taxpayers, including resident corporations, regarding their investments in foreign (i.e. other European) countries. In other words, Member States may not impose restrictions on their resident companies that make it less attractive (or more burdensome) for them to invest in another EU Member State than domestically.

Because the CFC rules of Member States apply only to the holdings of a domestic parent in a foreign subsidiary, subsidiaries that are resident in the same Member State as the parent do not fall within the scope of the CFC rules. This raises questions as to the compatibility of Member States' CFC rules with the EC Treaty. In the Lankhorst-Hohorst case, the ECJ made it very clear that any distinction between the tax treatment of foreign companies and that of domestic companies is incompatible with the EC Treaty if the differential treatment operates to the detriment of foreign companies or investment by domestic companies in other EU Member States. The ECJ based its conclusion in Lankhorst-Hohorst on the fact that the German thin capitalization rules do not apply to domestic shareholders.

CFC regimes involve a similar type of differential treatment: profits earned by a domestic subsidiary are sheltered against taxation at the level of the domestic parent; on the other hand, income earned by a foreign subsidiary, under certain conditions, is deemed to be distributed to the parent and taxed at the level of the parent. This constitutes a restriction of the freedom of the domestic parent to make an investment in a subsidiary in another EU Member State.

The arguments raised by Member States to defend their CFC legislation against challenges under the EC

Notes

ECJ decisions in Leur Bloom, C-28/95, 1997, ECR, 4161; Denkavit, C-283/94, ECR 1996, 5063; and ICI, C-264-96, 1998, ECR, 4695.

C-324/00 of 12 December 2002 - currently available at http://www.curia.eu.int.

For example, Denmark, Finland, France, Germany, Italy, Portugal, Spain, Sweden and the United Kingdom.

E.g. Italy, Portugal, Spain. 
Treaty have a familiar ring, having been used in past ECJ cases involving direct taxation.

A common argument that has been rejected by the ECJ is that many Member States have adopted CFC rules and such rules also were recommended by the OECD in its 1998 Report on CFC legislation. In other cases decided in the past, the ECJ has repeatedly rejected arguments raised by Member States even in cases where most, if not all, Member States have submitted the same argument to the court. ${ }^{5}$

The argument that CFC laws are necessary to protect the domestic tax base against erosion is not a valid argument according to the ECJ. The fact that a domestic parent company may invest in a foreign subsidiary in another EU Member State, rather than in a domestic subsidiary, does not justify the introduction of restrictive tax laws. To the contrary, the objective of the EC Treaty is to make investments in other EU Member States as 'normal' and desirable as investments in the home country.

Another argument frequently raised by the tax authorities of Member States is that low taxation in the country of residence of a subsidiary is a valid justification for CFC rules. However, in its 1999 decision in Eurowings, ${ }^{6}$ the ECJ held that low taxation in another Member State is not a valid reason for a Member State to impose restrictions on the freedoms under the EC Treaty.

The only circumstance in which there is potentially valid justification for applying CFC legislation is where there is a lack of substance, which is a common feature of CFC structures. The 'artificial' structuring of an investment using a foreign corporation that lacks any real economic nexus with the country where it is incorporated is clearly the kind of avoidance of which the ECJ would surely not approve. However, it should be emphasized that the critical test in these circumstances is whether the same substance criteria are also applied to domestic legal entities. A Member State that recognizes domestic subsidiaries regardless of whether they have substance will find it very difficult to rely on the lack of substance argument in the case of a foreign subsidiary resident in another EU Member State. Member States that believe that lack of substance gives rise to tax avoidance concerns must address the problem in both domestic and foreign contexts if they are to preserve the validity of the lack of substance argument.

The Finnish Supreme Administrative Court, referred to above, rejected the taxpayer's argument that the Finnish CFC rules are incompatible with the EC Treaty, but the Court's reasoning is not convincing. It is also clearly in conflict with Art. 234, para. 3 of the EC Treaty. According to that provision, a court against whose decision there is no judicial remedy under national law, must submit a case to the ECJ unless it is absolutely clear that the answer to the relevant question can not affect the outcome of the case. ${ }^{7}$ An obligation to submit a preliminary ruling request to the ECJ is also not required where the issue is materially identical to an issue that has already been the subject of a preliminary ruling in a similar case or if the correct application of Community law is so obvious as to leave no scope for any reasonable doubt as to the manner in which the issue is to be resolved. ${ }^{8}$

Given the widespread use of CFC legislation by Member States and the apparent mismatch of the tax treatment of foreign subsidiaries and that of domestic subsidiaries under Member States' CFC rules, it is surely only a matter of time before the ECJ will have the opportunity to address the compatibility of those rules with the EC Treaty.

\section{Notes}

5 As Lang, IStR 2002, at p. 218, rightly points out, the fact that many Member States have adopted tax laws that are incompatible with the EC Treaty exacerbates the EC law issue, rather than mitigates it.

6 C-294/97, ECR 1999, I-7449, 7463.

Another recent case dealing with an EU Member State's CFC legislation, i.e. the Schneider Electric case, did not require the French Conseil d'Etat to raise the question of compatibility with EC law because the case concerned a French parent company and its Swiss subsidiary.

8 CILFIT, C-283/81 of 6 October 1982, ECR 1982, 3415. 